\title{
Making the Shift from School Manager to Instructional Leader: Using the Nature of Technology Framework as a Tool for Analysis
}

\author{
Jerrid Kruse $^{1} \&$ Thomas Buckmiller ${ }^{1, *}$ \\ ${ }^{1}$ Leadership and Counseling Department, Drake University, Des Moines, IA 50311, USA \\ *Corresponding author: Leadership and Counseling Department, Drake University, Des \\ Moines, IA 50311, USA. E-mail: thomas.buckmiller@drake.edu
}

Received: November 4, 2014 Accepted: January 15, 2015 Published: January 27, 2015

doi:10.5296/ije.v7i1.6554 URL: http://dx.doi.org/10.5296/ije.v7i1.6554

\begin{abstract}
This exploratory study used qualitative methods to investigate the use of an emerging conceptual framework, the nature of technology, to understand ways in which future school administrators consider adopting new technology for their school. The nature of technology conceptual framework proved useful for investigating aspiring administrators' views related to technology use and adoption, and it has the potential to be used and applied in other contexts. The results of this study revealed these aspiring school administrators gave overwhelming precedence to managerial issues, as opposed to instructional leadership issues, when considering technology implementation.
\end{abstract}

Keywords: Education leadership, school administration, technology, nature of technology, instructional leadership, technology implementation. 
Technology plays an important role in education. A perusal through most educational technology journals yields a seemingly optimistic view of technology use in education; with the most commonly identified problem being a need for more technology use in schools. However, the push for technology in education ignores fundamental aspects of technological literacy and instructional leadership. For example, every advantage technology affords, comes a corresponding disadvantage (Postman, 1995). Olson and Clough (2001) highlight the manner in which technology can undermine our most lofty goals in education. Oftentimes, technology becomes a shiny new veneer on traditional methods (Ely, 1995; Lazlo \& Castro, 1995; Fraser \& Deane, 1999). However, adopting a staunch anti-technology view is also problematic and unproductive for school leaders.

We sought a framework that would be useful in evaluating whether school leaders make technology decisions based on a management principles or instructional leadership principles. School leaders ought to be able to harness technology to improve students' education while asking the critical question, "Does this technology facilitate learning?" School administrators should fully understand this paradox - supporting technological advancement within their schools while raising issues concerning what might be lost by adopting new technologies.

As school leaders develop their vision for technology adoption and integration in their school building, it seems obvious that they use multiple measures of data to drive decision-making and self-improvements in their skills and knowledge of technology. Yet, McLeod (2011) notes that there is little research that pays attention to technology-related leadership issues, and it is unclear as to what it means to be an effective school technology leader. If current trends continue, schools will continue to face pressure to adopt more digital, mobile, and multimedia technology. Schools cannot progress toward the adoption of effective and worthwhile new technologies if school leaders do not understand the implications of digital media and technology as well as the impact, both positive and negative, it can have in classrooms.

Many studies support the assertion that the administrator plays a pivotal role as the district or school technology leader (Anderson \& Dexter, 2005; Dikkers, Hughes, \& McLeod, 2005; Fletcher, 2009; Gerard, Bowyer, \& Linn, 2008; International Society for Technology in Education, 2007; McLeod, 2011; Slenning, 2000). Yet, few of these calls to increase the technology use in schools acknowledge the trade-offs associated with technology use. Unfortunately, the ability to critically evaluate technology is rarely seen as a necessary attribute of school leaders.

\section{Purpose}

The purpose of this exploratory study was to (1) determine the utility of a Nature of Technology (NOT) framework to investigate school leaders' thinking regarding technology and (2) identify ways in which future school administrators consider technological trade-offs regarding educational technology adoption. While recognizing the benefit of technology use in schools is of utmost importance, school leaders must be able to critically assess proposals 
and avoid jumping on technological bandwagons. Inherent in technology proposals is the hope that the technology will help students, teachers, and administrators in the teaching and learning process. This study hopes to shed light on how future school administrators weigh the gains and losses of educational technology use and adoption. To that end, our research question asked, "In what ways do aspiring school administrators (graduate students) describe technological trade-offs with respect to students' learning, teachers' teaching, and schools' culture when considering educational technological adoption?"

\section{Theoretical and Conceptual Frameworks}

\subsection{The Shift of Responsibility: From School Manager to Instructional Leader}

Defining school management is difficult, because as Bush (2011) observed there is no single generally accepted definition as its development has drawn heavily on several more firmly established disciplines including: sociology, political science, economics, and general management. Sapre's (2002) explanation provides a starting point for this discussion, "Management is a set of activities directed toward the efficient and effective utilization of organizational resources in order to achieve organizational goals" (p.102). Typically, a school principal's management duties are those that deal with the day-to-day operations of the school facility. These responsibilities may include discipline, compliance, scheduling, resource allocation, and personnel issues. Horng, Klask, and Loeb (2010) indicated that principals spend the majority of their work on managerial activities. Walker (2010) indicated that principals are increasingly under pressure to perform managerial duties which may distract them from other responsibilities including instructional leadership.

Within the past 30 years, however, the expectations of the role of the school principal have changed (McEwan, 2003). Gupton (2010) said that an examination of today's effective principal reveals that the most critical role shift is from a managerial orientation to an instructional leadership orientation. Today's educational leader is expected to focus more on issues of instructional leadership in ways that develop and support collaboration while still focused on teaching and learning (Green, 2010). McEwan (2003) observed:

An assignment given to the typical graduate student in educational administration in the seventies or early eighties was to develop a list of jobs in the seven traditional administrative task area (staff personnel, pupil personnel, school-community, instructional and curriculum development, finance and business management, facilities management, and intergovernmental agency relations) as they relate to the four classic management functions (planning, organizing, leading, and controlling). Today's educational administrator in training must add an additional assignment — to become an instructional leader. (p. 2)

Cooley and Shen (2003) assert that principals, as instructional leaders, need a laser-like focus on accountability for student achievement. The effective schools movement of the 1980s inevitably coined the term "instructional leadership", and it has become a significant part of the vocabulary of educational administration and leadership ever since (Hallinger, 2005). Shellard (2003) said that instructional leadership refers to the knowledge and skills principals 
possess to effectively support the academic program. In other words, instructional leadership involves doing things that improve teaching and learning while gathering evidence of student achievement that demonstrates improvement (King, 2002).

Robinson, Lloyd, and Rowe (2008) determined that the closer principals are to teaching and learning in schools, the more likely they are to have a positive effect on student outcomes. This means that instructional leaders must be prepared to focus time, attention, and effort on changing what students are taught, how they are taught, and what they learned (Bottoms \& O’Neill, 2001). Blasé and Blasé (1999) indicated the significant practices of instructional leadership that emerged in their study: (a) talking with teachers to promote reflection; (b) promoting professional growth; and (c) fostering teacher reflection.

Leading professional development and supporting professional learning communities are two of the primary ways that a principal demonstrates instructional leadership. Walker (2010) said that school leaders build organizational capacity by providing professional development for best practice aligned with student needs and ensuring that teachers have the resources and appropriate conditions to enable quality teaching and learning. Seashore-Louis, Leithwood, Wahlstrom, and Anderson's (2010) research found that leadership effects on student learning occur largely because the school's leadership strengthened the professional community. The teacher's engagement in a professional community, in turn, fosters the use of instructional practices that are associated with student achievement.

The shift to spend more time on matters of teaching and learning may not be natural or easy for school principals. Within a district or school, the conditions must be favorable for a principal to focus on instructional leadership. Although the authors of this study do not think that all of the administrator's responsibilities and duties fall in the either/or binary of managerial or instructional leadership, it is our position that there are certain activities that generally reduce the principal's focus and time away from instructional leadership. As such, we regard instructional leadership as a blend of several tasks including supervision of classroom instruction, staff development, and curriculum development (Smith \& Andrews, 1989).

\subsection{The Nature of Technology (NOT)}

Although the NOT is a rather new framework, some consensus is beginning to emerge (e.g. Digironimo, 2011; Kruse \& Wilcox, 2013; Kruse, 2013a; Mitcham, 1994; Waight \& Abd-El-Khalick, 2012). Importantly, as scholars have noted with the nature of science (e.g. Clough, 2007), the NOT is better approached as a series of questions with which to wrestle rather than prescriptive tenets. Some questions raised within NOT discussions include (Kruse, 2013a):

- What is technology?

- In what way are technologies value-laden?

- What are the trade-offs (gains and losses) of technology use?

- What are the limitations of technology? 
- In what ways are new technologies connected to the past?

- In what way does technology implementation depend upon and influence broader contexts (society, classrooms, etc.)?

While raising questions reflect the nuanced and contextualized nature of technological decision-making, we agree with Keen (2008) and Mitcham (1994) who note that questioning must accompany engagement with the technology. That is, a critical stance is not as robust without grounding in familiarity with technology. The NOT framework guided us as we developed questions to ask participants in this study to help us evaluate how they would make technology decisions.

The need to think critically about technology is becoming more necessary as technology becomes more prevalent in our lives. That is, critical consumers of technology need to study the psychic and social consequences of technology (McLuhan, 1964). We believe there are important attributes of the NOT that can guide a more effective and informed technology use and adoption. For this study, technological trade-offs was a focus, because that construct was more concrete than other aspects of the NOT while shedding light on participants views toward decisions regarding technology.

\subsection{What Are the Trade-offs of Technology Use?}

The existence of trade-offs is well accepted by philosophers of technology. Postman (1995) succinctly summarizes the nature of technological trade-offs when he writes:

[Technologies] are Faustian bargains, giving and taking away, sometimes in equal measure, sometimes more in one way than the other. It is strange-indeed, shocking - that with the twenty-first century so close on our heels, we can still talk of new technologies as if they were unmixed blessings, gifts, as it were, from the gods. Don't we all know what the combustion engine has done for us and against us? What television is doing for us and against us? (p. 41)

While other philosophers have used different language, each discussed technological trade-offs in one fashion or another. For example, Ihde (1979) discusses amplification and reduction, McLuhan (1964) discusses "psychic and social consequences" (p. 233), and Ellul (1964) notes how "every technical advance is matched by a negative reverse side" (p. 106).

While thinking about trade-offs requires consideration of what is gained as well as what is lost, too often discussions focus solely on what is gained. That is, people have long believed technological pursuits to be divine in nature and hold powers of salvation (Noble, 1999). This tendency for technology to be "uncritically worshipped" (Ellul, 1964, p. xi) prevents consideration of the consequences, losses, or negative sides of technology.

\subsection{Invisibility of Technological Trade-offs}

Unfortunately, given the many benefits of technological advancement, the negative consequences are difficult to notice. This lack of attention to both sides of technological trade-offs could be partially explained by technologies tendency to become invisible; 
particularly, as users become more familiar with the technologies (Heidegger, 1977; Ihde, 2009).

Indeed, such invisibility of technological trade-offs is one reason this study was undertaken - to investigate aspiring administrators' ability to consider these hard-to-see trade-offs. While philosophers of technology often articulate extreme views regarding the negative side of technology, the authors' views are a bit more tempered as will be discussed in our positionality below. First, consideration is given to why the NOT may be a useful framework in education and how such a framework has already been used to understand education-related phenomenon.

\subsection{The Value of a Nature of Technology Framework}

Understanding NOT constructs will help educators more carefully think through decisions regarding technology by asking questions such as:

What aspects of learning and understanding does technology engender? What is the specific nature of the identified cognitive, social, behavioral issues and how does technology serve as a fix? What are the specific mechanisms through which technologies respond to the nontechnical issues? (Waight \& Abd-El-Khalick, 2012, p. 25-26).

Waight and Abd-El-Khalick (2007) hinted at the utility of a NOT framework when trying to explain their investigation of a teacher well known for both inquiry-based science instruction and technological prowess. The researchers found that the level of inquiry suffered when technology was used, because students focused more on equitable sharing of the technology and trouble-shooting technological issues. That is, the technology changed the behavior of the students and the culture of the classroom.

Kruse (2013b) also worked with middle school students. He found that the $8^{\text {th }}$ graders were able to overcome many misconceptions related to the NOT when the students were asked to explicitly reflect on NOT ideas. Waight and Abd-El-Khalick (2012) proficiently used a NOT framework to critically assess efforts to implement technology as well as research on technology implementation in science education. For example, the authors noted that researchers tend to blame non-technological factors when getting less than desirable results indicating a lack of critical engagement with technology. Indeed, the researchers note that the lack of critical stance and misunderstanding of the NOT led to problematic interpretations of data.

\subsection{Positionality}

Tom Buckmiller teaches in the Masters of Science of Education Leadership at Drake University. As more K-12 schools consider adopting one-to-one laptop initiatives in the state of Iowa, aspiring school leaders need a thoughtful approach to the decision-making process regarding the adoption of new technology. Tom uses various digital technologies in his classroom including twitter, blogs, clickers, on-demand book printing, Google docs, and Dropbox.

Jerrid Kruse teaches science methods and educational technology courses for pre-service 
teachers and a doctorate level course on technology in leadership at Drake University. Jerrid uses technology in his classes such as: blogs, videos, twitter, and Google apps. As a middle school teacher, Jerrid, used technology extensively in his classroom. Yet, with all this use and experimenting with technology in educational settings, he began to notice ways in which the technology sometimes hindered students' learning or got in the way of student thinking.

The NOT framework could be used to simply dismiss all technology-based efforts in education. However, we think such a view is not prudent. This dismissive view that sees technology as inherently dangerous devalues human ability to control technology. Feenberg (2009) labels such a view as substantive. The authors do not hold to a substantive theory of technology, but we accept the value-laden NOT framework. Therefore, we subscribe to a critical theory of technology (Feenberg, 2009). That is, we believe technology is value-laden, but recognize that human beings still make choices that influence how technology is developed and used. Feenberg (2009) summarized a critical theory of technology as:

Critical theory agrees with substantivism that technology is not the unmixed blessing welcomed by instrumentalists and determinists. It recognizes the catastrophic consequences of technological development, but still sees a promise of greater freedom in a possible future. The problem is not with technology as such but with our failure so far to devise appropriate institutions for exercising human control over it. We could tame technology by submitting it to a more democratic process of design and development. (p. 164)

However, for such democratic processes to work, individuals must be more informed about the ways in which technology is value-laden. Therefore, Feenberg (2009) notes, "Critical theory is relatively skeptical about the capacity of human being to get technological civilisation (sic) under reasonable control, but at least it does not exclude the possibility in principle as does substantivism" (p. 165).

\section{Research Design}

\subsection{Methodology}

This study sought to explore aspiring administrators' views of technological trade-offs associated with school technology adoption. Additionally, the exploratory nature of this study sought to investigate the utility of a nature of technology (NOT) framework for investigating administrator thinking about technology. Collecting and analyzing qualitative data that might provide deep insight into participants' views best served the exploratory nature of this study.

\subsection{Research Participants and Study Context}

The participants in this study were recent graduates of an Educational Leadership Master's degree program from a mid-sized Midwestern university. Upon graduation these students received K-12 school administration licensure, and they are eligible to assume an administration position within a school. The participants came from four different cohorts in three different regions of the state. 
Following the Institutional Review Board's (IRB) approved protocol, participation in this study was voluntary and the researchers had no way of identifying who the respondents were. The researchers sent Qualtrics surveys to the emails accounts of these recent graduates. There were 26 respondents.

\subsection{Data Collection}

For this exploratory study, an e-mail containing a survey of six open-ended questions focused on how aspiring administrators evaluate educational technology. Guided by the NOT, the questions were:

1. If you were in charge of adopting technology in your school, what factors would you consider when making decisions regarding technology implementation in your school? For each factor you listed, explain your reasoning.

2. In the following questions a "trade-off" involves losing one quality or aspect of something in return for gaining another quality or aspect. For example, if I wanted my guitar to be louder, I could buy a bigger amplifier. However, a trade-off might be the increased weight and size for moving the amplifier. With that in mind...Your district is discussing a 1:1 initiative (every child receives a laptop). What trade-offs might exist for this initiative?

3. In what ways do you believe technology might improve student learning? If you are able, please provide examples to illustrate your answer.

4. What trade-offs might exist when using technology to improve student learning? If you are able, please provide examples to illustrate your answer.

5. In what ways do you believe technology might enhance pedagogy (teaching)? If you are able, please provide examples to illustrate your answer.

6. What trade-offs might exist when using technology to enhance pedagogy (teaching)? If you are able, please provide examples to illustrate your answer.

\subsection{Data Analysis}

The methods used in analyzing qualitative data stem from the grounded theory tradition (Glaser \& Strauss, 1967). Data were analyzed by open and axial coding (Strauss \& Corbin, 1998) using a constant comparative method in which codes and themes were developed from data analysis with reflexively refined as necessary (Maxwell, 2005). While grounded theory methods best describe the procedures and goals of data analysis in this study, data collection and analysis cannot be separated from previous theoretical commitments of the researcher (Emerson, Fretz, \& Shaw, 1995). Although data was constantly compared against itself, the researcher does not claim that themes "emerged" from data. Instead, a naturalistic inquiry (Lincoln \& Guba, 1985) stance was taken for data analysis. For example, participants' views were organized based on researchers' views regarding the dualistic nature of administrators' role: management and instructional leadership. Yet, within these themes, subthemes and patterns were sought based on available data sources.

In our analysis, we organized the data into two broad categories: statements that were focused 
primarily on management functions and statements that were focused primarily on instructional issues of teaching and learning. Since most everything a principal does during a school day has some connection to teaching and learning, using the descriptor "primarily" helped us categorize the thoughts in a meaningful way. To be categorized as an instructional issue, the statement had to be related to curriculum, instruction, learning, and/or assessment.

While a grounded theory methodology under a naturalistic inquiry theoretical framework might be perceived by some as problematic, the interaction reflects the tension apparent in the researchers' views. A naturalistic inquiry framework notes the dependence of knowledge on the knower while a grounded theory approach focuses on generating knowledge from data sources. Taking either of these views to extreme is unproductive. That is, to ignore the role of theoretical commitments or to ignore the relation of data to reality are both problematic. Therefore, using methods that strive to be "grounded" in data, while adopting a stance that accepts the theory-laden nature of data analysis, most accurately reflects the researchers' stance between positivism and postpositivism.

\section{Findings and Discussion}

\subsection{Management-oriented Trade-offs}

Funding seemed to be a predominant consideration for participants. When participants were asked what factors they would consider when making decisions regarding technology implementation in their school, the overwhelming majority of the responses focused on managerial considerations such as: cost, infrastructure, and teacher training. For example, one participant noted:

Funding is critical. Are there funds to support this? Professional development factors would involve determining if the staff is trained to use the technology appropriately. Another issue involves the current server. Will this have to be upgraded? Can it support the new technology at a speed that the students will stay engaged?

The responsibility of the principal to be aware of a school's budget seemed important to the participants. When presented with a scenario for adopting a one-to-one laptop initiative, one participant indicated she would need to take time to consider a cost benefit analysis; while another participant wanted to know how much it would cost initially and how much it would cost to maintain the system. Another participant said the following:

This initiative is a very costly one. Not only are the students receiving laptops, other factors such as time to fix the computers, updating software and monitoring appropriate usage. Besides the initial cost, the cost of repairs, added software and upgrades cost money.

Another participant explained, "More funds will be needed to keep the laptops up-to-date, replace batteries, etc." A different participant even noted, "Money for other things (textbooks, etc.) will be impacted." Yet another participant stated the importance of having funding to support laptops that are lost or stolen. 
The participants' consideration of cost, infrastructure, and teacher training were nuanced and well developed. Take for example this participant's response:

What is the sustainability cost? With technology there is usually an upfront cost, but you also need to consider the cost of keeping the technology going such as maintenance, district licensing, professional development for current and new staff, and upgrades.

Related to cost, many participants noted that planning for professional development time would be required to help teachers learn how to use the new technologies. While none of the participants dwelt on this theme, when it was mentioned, it was done so in passing. Most statements were concerned with the costs associated with bringing in trainers for the new technology. For example, one participant said, "The budget is tight and we would need certain funding for training," and another mentioned they would have to guarantee that there is "time and money" for professional development.

The issue of time surfaced in a couple statements. Participants noted that it would take a significant amount of time for teachers to learn and implement certain technologies. For example, one participant stated "Teachers might lose instructional time if they have to take time to teach how to use the technology." Another said, "If the technology does not work or if the teacher is not as familiar with it as she should be, time will be lost." Other participants noted a "high learning curve for teachers" and the time teachers will need to plan for technology use.

Infrastructure was another concerned that surfaced throughout the participant responses. While some were concerned about the cost of a new infrastructure, several raised concerns regarding the need for improved infrastructure. This led to another management issue that dealt with finding space, both physical and virtual, namely classrooms, equipment storage, and bandwidth. A few participants noted the school would need to increase the school's bandwidth and one participant noted, "We will need a larger server to handle the increased traffic." One participant expressed a concern for physical storage "for when the laptops are not in use," and another brought up the logistical issue of dealing with transportable lab carts: how they would be transported, who would get priority to use them, and where they would be stored. Other participants noted the increased security issue given that, "Laptops could be more vulnerable to virus/malware as they will most likely be taken home for use and thus off the district's network." Clearly students understood the importance of infrastructure as a key piece of understanding prior to adopting a one-to-one laptop initiative.

Another sub-topic, classroom management and student distraction, surfaced in the management-related theme. One participant wrote:

I worry about not being able to control what students are able to do during class. For example, if you ask students to read out of a textbook, a teacher can easily look around the classroom to make sure students have out that textbook. With computers, it is a lot harder to glance around the room and make sure students are on task.

It was apparent that some participants had concerns about the notion that social networks, apps, and the internet, in general, will cause students to be off task during a class. In 
particular, one participant said, "Students will have access to technology, but will they be working on the assigned tasks or using social networks?" Another participant observed, "Students may become distracted by other Internet applications instead of the task at hand." A couple participants mentioned there would have to be increased supervision and accountability, so students would not download inappropriate content. Finally, one participant noted, "Students may not pay attention to the lesson due to having a laptop in front of their face that is on, they may want to surf the Internet during instruction."

\subsection{Instruction-oriented Trade-offs}

Participant responses were not as detailed in regard to how technology might impact teaching and learning - further exemplifying their emphasis on managerial concerns related to technology integration. While managerial aspects are important considerations, participants were explicitly prompted to consider teaching and learning issues. Unfortunately, even when prompted the participant responses seemed underdeveloped.

Some participants included consideration of student learning as minor components of their response including phrases such as, "I would want to know what will be gained by the students." Overwhelmingly, participants focused on how technology integration might improve teaching and learning, even when asked to consider the negative impact of technology on learning. Common ideas developed regarding participants' views of how technology might improve teaching and learning included: preparation for the real world, learner differences, increased opportunity, and increased engagement.

More specifically, some participants noted that, "Students will be able to work at their own pace," while others discussed how teachers "can supplement [instruction] through videos, websites, or pictures." Some other participants focused on potential for differentiation. For example, one participant wrote:

I think technology can improve student learning by allowing them to see another way to learn. There are so many visuals on the computer that students can see, and there is also audio which would allow students to hear a lesson and take their time working on a subject that they may have a hard time understanding.

The idea of loss of traditional skills and social interaction seemed to be on the minds of the participants. When participants were explicitly prompted to explore the trade-offs of technology in relation to teaching and learning, they typically focused on skill development rather than conceptual learning or student thinking. Some of the participants were concerned that increased use of technology would lead to a decrease in other traditional social skills: namely writing, speaking and communicating. One participant, in particular, wondered if students' speaking abilities might decrease, "Are they using correct grammar and sentence structure or are they using 'texting' language?" Another participant predicted that students and teachers would lose the face-to-face interactions as technology will replace the necessity for these interactions. One participant went a bit deeper wondering if schools would one day even, "Eliminate areas that do not lend themselves to the technology integration."

When asked about trade-offs for student learning, the participants seemed to focus on the 
interaction between teacher and student. For example one participant noted there would be, "Less personal contact with a teacher" which was similar to another concern, "Less time with the teacher -- the 'human factor'". Finally, one participant wondered if students would have a difficult time transitioning "back" to a classroom where technology is not used as much. While these concerns are valid, most participants did not connect such concerns to student learning or how such ramifications might impact the way in which students think or the depth of their learning.

A few participants did expressed concerns related to a loss related to thinking, learning, and teaching, but these concerns were rare. One participant wrote:

How is the technology going to increase student achievement? Will it enhance ability to communicate (read, write, speak), increase collaborative opportunities, increase rigor, and/or cause students to think and solve problems at higher levels than we are currently doing?

Not only was consideration of how technology will impact student learning rarely considered, the participants seemed to assume technology integration results in either gain or no gain. Even with explicit prompting regarding trade-offs for thinking, learning, and teaching, participants' responses only rarely addressed what might be lost with technology integration.

However, four of the twenty-six participants' responses did address loss in relation to thinking and teaching. One participant noted that the 1:1 initiative might cause, "Loss of original thought...because all of the information they will have access to, they may be more likely to recycle others' ideas." Indeed, Keen (2008) has noted this problem within the journalism community. Rather than fresh insight, some bloggers have recycled credible journalists' hard work which may undermine the very institution of journalism. Parallels to education are important questions to address.

Ease of access to information and lack of critical thought were common among those participants who identified possible trade-offs related to student thinking. For example, one participant wrote, "Higher order thinking skills developed through concentrated analysis of reading, writing, speaking, and listening could easily be replaced with virtual worksheets that only challenge students through recall."

Another participant echoed this concern when they said, "Students are able to get the answers quickly without much reasoning just by looking something up." While these outcomes are not predetermined, the fact that more participants are not raising such issues is cause for concern - particularly when participants were explicitly asked to consider negative impacts on student learning. Importantly, these issues can be addressed, but instructional leaders must be able to consider such pitfalls so that active measures can be taken to encourage deeper learning for students.

Another participant worried that new technology might distract from teaching and learning in more profound ways. The participant wrote:

Technology will be at the fingertips of every student, but the use of that technology may actually distract from teaching and learning. Schmoker discusses the use of the "crayola 
curriculum" to describe posters and artwork that distract from authentic learning. I would worry that a trade off for some teachers and students would be that they would lose sight of sound practices for flashy application of technology with no real substance for teaching or learning.

While this participant is worried about distraction, the concern seems to run much deeper than distracted attention. This participant mirrors Okan's (2003) concern with the erosion of education to "edutainment". These considerations of technological trade-offs concerning student thinking are deep issues with which educators ought to wrestle.

\section{Conclusions}

This exploratory study yielded two important conclusions. First, the nature of technology (NOT) conceptual framework is a useful lens through which to investigate administrator thinking. By asking aspiring administrators to consider the technological trade-offs construct of the NOT, light was shed on participants' thinking regarding technology adoption. Not only did the NOT framework help form the questions asked, but it was also useful when working to make sense of the data. Especially, when combined with the theoretical framework regarding the difference between managerial and instructional leadership.

The authors suspect other aspects of the NOT framework might be useful for investigating school administrators' thinking regarding technology as well as help explain and/or account for particular stances on technology adoption. For example, administrators, who are resistant to technology adoption, might hold extreme views regarding the value-laden NOT or only recognize negative aspects of technological trade-offs without acknowledging positive impacts of technology. Similarly, an administrator who holds unrealistic expectations for technology to change instructional practices of teachers may not understand the limited nature of technology.

A second conclusion is that the future administrators in this study gave overwhelming precedence to managerial-based concerns, as opposed to instruction-based concerns when asked to consider technological trade-offs. Given the lack of consideration of the nature of technology in the future administrators' program and in our society generally, this conclusion is not surprising. This study revealed that future administrators are not considering philosophical aspects of technology and deep trade-offs related to teaching and learning. Instead, the data from this exploratory study demonstrate that the aspiring administrators are most concerned with pragmatic details such as cost, time, and infrastructure. Even when the future administrators mentioned the classroom or student learning, they focused on managerial tasks such as classroom management, students learning the technology, possible outages, and etc. Unfortunately, very few participants considered the deep impact technology might have on student learning, and they only did so when explicitly prompted.

These findings raise questions about the deep seeded views the future administrators have about their role in schools. How can education leadership programs adapt to help future administrators more deeply internalize their role as an instructional leader? How can 
understanding the nature of technology help better equip future administrators to make sound decisions regarding technology implementation?

\section{Implications}

\subsection{Management vs. Instructional Leadership}

Despite their desire to become instructional leaders, these participants, who are aspiring school principals, seemed to spend a lot of time thinking about what are traditionally management-driven decisions as they considered issues of adopting new technology. Educators acknowledge, and research confirms, that management tasks greatly reduce the time and focus that principals can devote to instructional leadership; however, administrators have been unable to find ways to eliminate these tasks as barriers (Making Time, 2009). Walker (2010) suggested, "Building leaders need to be relieved of some the management tasks that pull them away from their primary instructional responsibilities" (p.10). It seems the mindset of these future principals were geared toward these typical management issues such as budgeting, planning, time, classroom management/discipline, and so forth. This is not an attempt to characterize school management duties as unimportant. Certainly, paying attention to issues of the budget, infrastructure, and facilities are important. But as noted in Making Time (2009), "The problem is that often times principals spend too much time 'in the weeds' taking care of pressing management demands and not enough time on instructional leadership tasks" (p. 8).

The International Society for Teachers in Education (ISTE) created the National Educational Technology Standards for Administrators (NETS-A) to guide principal development. The five primary standards emphasize: visionary leadership, digital age learning culture, excellence in professional practice, systemic improvement, and digital citizenship (ISTE, 2009). Enmeshed within these standards are a number of descriptors. The majority of these descriptors seem to fall under the instructional leadership category as opposed to the managerial role. Examples of these descriptors include: nurture instructional innovation while focused on continuous improvement of digital-age learning; encourage evaluation of new technologies for their potential to improve student learning; and lead purposeful change to maximize the achievement of learning goals through the appropriate use of technology and media-rich resources (ISTE, 2009).

Importantly, understanding the NOT should help administrators achieve the goals put forth by the ISTE. For example, a critical understanding of technological trade-offs would help administrators more deeply evaluate technologies for their possible impact on student learning. However, analysis of technological trade-offs would be severely limited if administrators focus on managerial trade-offs such as increased costs over instructional trade-offs related to teaching and learning such as more abstract representation of content (e.g. Olson \& Clough, 2001).

If, as the literature suggests, the role of the principal is shifting from manager to instructional leader, then the mindset of future school leaders needs to shift also. Unfortunately, the 
participants of this study continued to focus most on managerial issues. To the extent this focus extends beyond consideration of technology in schools, we cannot know from this study. However, the participants' focus on managerial issues may indicate a need to explicitly address educational technology and instructional leadership within administrator education programs.

The role of the principal-as-manager is a pervasive notion. Despite having learned how to be instructional leaders, these aspiring administrators may still retain some of their old and deeply held beliefs about educational leadership. Importantly, discussion about how instructional leadership might apply to educational technology was not a focus of the program in which these participants were enrolled. When given the new context of instructional technology, most of the aspiring administrators seem to have focused more on managerial issues concerning technology integration.

The findings of this study may indicate that participants lack depth of understanding of teaching and learning. Much of what the participants said about how technology might impact teaching and learning was overly generalized or superficial. To consider more nuanced impacts of technology in schools, instructional leaders must have more nuanced understandings of teaching and learning. Unfortunately, very few of the participants' responses addressed issues related to the depth of student learning or made explicit reference to student thinking.

\subsection{The Nature of Technology}

As with aspiring educators (Kruse, 2012), the participants of this study seem to have limited understanding of the nature of technology. This claim is supported by participants only considering simplistic technological trade-offs such as distraction or loss of "traditional" skills. Such concerns are not unique to modern technology. That is, distraction has always been a problem in schools. Had the participants deeply understood the nature of technology, they might note how technology changes the way people think and act in unexpected ways. For example, an aspiring administrator with a deep understanding of the nature of technology may wonder how a 1:1 laptop initiative might reinforce more independent work by students (e.g. Guzman-Rodriguez, 2007; Kruse, 2013b) or how technology might shift focus away from content learning toward technology fluency (e.g. Waight \& Abd-El-Khalick, 2007). As noted in the findings, some participants did propose such "deep" trade-offs. However, the overwhelming majority of participants focused more exclusively on managerial concerns or only superficial learning trade-offs such as student distraction.

Knowing that technology comes with what Postman (1995) calls Faustian bargains is likely not enough to consider deep technological trade-offs. Instructional leaders must also recognize how the value-laden nature of technology might contribute to technological trade-offs. Making clear that technology is value-laden, Broughton (1985) explains:

High technology, too, is value laden. The computer embodies a certain kind of rationality; that rationality is the condition of the possibility of computer technology, its fundamental presupposition. Apparatuses and techniques do not occupy some privileged sphere sanitized 
of affective, moral, or political qualities. These qualities are not subjective infections to be eliminated with the right disinfectant, so that the purity of truth is left shining before us. Material products of human labor contain the policies through which they were intentionally constituted, whether those subjective purposes ever reach consciousness or not. (p. 103)

Broughton's ideas apply particularly well to technology integration in education. For example, deep learning is an unpredictable and time-consuming process. Yet, technologies are designed with a high emphasis placed on efficiency (Ellul, 1964). When we use technologies designed for efficiency to "enhance" an inherently inefficient process, one wonders how the bias of the technology powerfully shifts the manner in which teaching and learning are pursued. Okan (2003) mirrors this concern when noting that much educational software may cause an "inflated expectation in the learners that the process of learning should always be colorful and fun, and that they can acquire information without work and serious study" ( $\mathrm{p}$. 255). Importantly, concerns such as those mentioned in this section can only be raised and addressed if educators, including instructional leaders, understand the nature of technology.

\section{References}

Anderson, R. E., \& Dexter, S. (2005). School technology leadership: An empirical investigation of prevalence and effect. Educational Administration Quarterly, 41(1), 49-82. http://dx.doi.org/10.1177/0013161X04269517

Blasé, J., \& Blasé, J. (1999). Principals' instructional leadership and teacher development: Teachers' perspectives. Educational Administration Quarterly, 35(3), 349-378. http://dx.doi.org/10.1177/0013161X99353003

Bottoms, G., \& O’Neill, K. (2011). Preparing a new breed of school principals: It's time for action. Atlanta, GA: Southern Regional Education Board.

Broughton, J.M. (1985). The surrender of control: Computer literacy as political socialization of the child. In D. Sloan (Ed.). The computer in education: A critical perspective. New York, NY: Teachers College Press.

Bush, T. (2011). Theories of educational leadership and management. Los Angeles, CA: Sage.

Clough, M. P. (2007, January). Teaching the nature of science to secondary and post-secondary students: Questions rather than tenets. The Pantaneto Forum, 25, p. 31-40. http://www.pantaneto.co.uk/issue25/clough.htm

Cooley, V. E., \& Shen, J. (2003). School accountability and professional job responsibilities: A perspective from secondary principals. NASSP Bulletin, 87(634), 10-25. http://dx.doi.org/10.1177/019263650308763402

DiGironimo, N. (2011). What is technology? Investigating student conceptions about the nature of technology. International Journal of Science Education, 33(10), 1337-1352. http://dx.doi.org/10.1080/09500693.2010.495400 
Dikkers, A. G., Hughes, J. E., \& McLeod, S. (2005). A bridge to success: STLI. T.H.E. Journal, 32(11), 20-24.

Ellul, J. (1964). The Technological Society. New York, NY: Vintage Books.

Ely, D.P. (1995). Technology is the answer! But what was the question? The James P. Curtis Distinguished Lecture, Capstone College of Education Society, College of Education, University of Alabama, April 14, 1995.

Emerson, R.M., Fretz, R.I., \& Shaw, L.L. (1995). Writing ethnographic fieldnotes. The University of Chicago Press: Chicago and London. http://dx.doi.org/10.7208/chicago/9780226206851.001.0001

Feenberg, A. (2009). What is philosophy of technology? In Jones, A.T. \& de Vries, M.J. (Eds.) International Handbook of Research and Development in Technology Education, 159-166. Boston, MA: Sense Publishers.

Fletcher, G. H. (2009). A matter of principals. T.H.E. Journal, 36(5), 22-28.

Fraser, S. P., \& Deane, E. M. (1999). Educating tomorrow's scientists: IT as a tool, not an educator. Teaching in Higher Education 4(1), 91-106. http://dx.doi.org/10.1080/1356251990040106

Gerard, L. F., Bowyer, J. B., \& Linn, M. C. (2008). Principal leadership for technology-enhanced learning in science. Journal of Science Education and Technology, 17(1), 1-18. http://dx.doi.org/10.1007/s10956-007-9070-6

Glaser, B.G., \& Strauss, A.L. (1967). The discovery of grounded theory: Strategies for qualitative research. Hawthorne, NY: Aldine.

Green, R. L. (2010). The four dimensions of principal leadership: A framework for leading $21^{\text {st }}$ century schools. Boston, MA: Allyn \& Bacon.

Gupton, S. L. (2010). The instructional leadership toolbox: A handbook from improving practice. Thousand Oaks, CA: Corwin Press.

Guzman-Rodriguez, S.M. (2007). Community college students' plant biodiversity learning experiences in an introductory biology course: Exploring the value added by using a $C D-R O M$ to develop inquiry lessons. Unpublished Doctoral Dissertation, Louisiana State University.

Hallinger, P. (2005). Instructional leadership and the school principal: A passing fancy that refuses to fade away. Leadership and Policy in Schools, 4, 1-2. http://dx.doi.org/10.1080/15700760500244793

Heidegger, M. (1977). The question concerning technology and other essays. New York: Harper Perennial.

Horng, E. L., Klask, D., \& Loeb, S. (2010). Principal's time-use and school effectiveness. American Journal of Education, 116, 491-523. http://dx.doi.org/10.1086/653625 
Ihde, D. (1979). Technics and praxis (Vol. 24). Dordrecht: Reidel. http://dx.doi.org/10.1007/978-94-009-9900-8_2

Ihde, D. (2009). Whole earth measurements. In Jones, A.T. \& de Vries, M.J. (Eds.), International handbook of research and development in technology education, 151-158. Boston, MA: Sense Publishers.

International Society for Technology in Education (2007). National Educational Technology Standards.

ISTE. (2009). NETS for administrators 2009. Retrieved from http://www.iste.org/Content/NavigationMenu/NETS/ForAdministrators/2009Standards/ NETS_for_Administrators_2009.htm

Keen, A. (2008). The cult of the amateur. New York, NY: Doubleday.

King, D. (2002). The changing shape of leadership. Educational leadership. 59(8), 61-63.

Kruse, J.W., \& Wilcox, J.L. (2013). Engaging students with the nature of science and the nature of technology by modeling the work of scientists. The Clearing House, 86, 109-115. http://dx.doi.org/10.1007/978-94-6209-269-3_18

Kruse, J. (2013a). Implications of the nature of technology for teaching and teacher education. In Clough, M.P., Olson, J.K., \& Niederhauser, D. (Eds.), The nature of technology: Implications for learning and teaching. Boston, MA: Sense Publishers.

Kruse, J. (2013b). Promoting middle school students' understanding of the nature of technology. In Clough, Olson, \& Niederhauser (Eds.), The nature of technology: Implications for learning and teaching.

Lazlo, A., \& Castro, K. (1995). Technology and values: Interactive learning environments for future generations. Educational Technology, March/April, 7-13.

Lincoln, Y., \& Guba, E. (1985). Naturalistic inquiry. Newbury Park, CA: Sage Publications.

Maxwell, J.A. (2005). Qualitative research design: An interactive approach (2 ${ }^{\text {nd }}$ Ed.). Thousand Oaks, CA: Sage.

McEwan, E. K. (2003). 10 traits of highly effective principals: From good to great performances. Thousand Oaks, CA: Corwin Press.

McLeod (2011). Are we irrelevant to the digital, global world in which we now live? UCEA Review, Summer, 1-5.

McLuhan, M. (1964). Understanding media: The extensions of man. Critical Edition edited by W. Terrence Gordon. Berkeley, CA: Gingko Press.

Mitcham, C. (1994). Thinking through technology: The path between engineering and philosophy. Chicago, IL: The University of Chicago Press. 
National SAM Project. (2009). Making Time. Retrieved from http://www.wallacefoundation.org/principal-story/vignettes-and-conversation-guides/Pa ges/sam-project.aspx

Noble, D.F. (1999). The religion of technology: The divinity of man and the spirit of invention. New York, NY: Penguin Books.

Okan, Z. (2003). Edutainment: Is learning at risk? British Journal of Educational Technology, 34(3), 255-264. http://dx.doi.org/10.1111/1467-8535.00325

Olson, J.K., \& Clough, M.P. (2001). Technology's tendency to undermine serious study: A cautionary note. The Clearing House, 75(1), 8-13. http://dx.doi.org/10.1080/00098650109599225

Postman, N. (1995). The end of education: Redefining the value of school. New York, NY: Vintage Books.

Richardson, J.W., \& McLeod, S. (2011). Technology leadership in Native American schools. Journal of Research in Rural Education, 26(7). Retrieved from http://jrre.psu.edu/articles/26-7.pdf

Robinson, V. M. J., Lloyd, C., \& Rowe, K. J. (2008). The impact of leadership on student outcomes: An analysis of the differential effects of leadership type. Educational $\begin{array}{lllll}\text { Administration } & \text { Quarterly, } & 44(5), & 635 & -\end{array} 674$. http://dx.doi.org/10.1177/0013161X08321509

Sapre, P. (2002). Realizing the potential of educational management in India. Education Management and Administration, 30(1), 101-108. http://dx.doi.org/10.1177/0263211X020301001

Seashore-Louis, K., Wahlstrom, K. L., Leithwood, K. and Anderson, S. E. (2010). Investigating the Links to Improved Student Learning. The Wallace Foundation. Retrieved from http://www.wallacefoundation.org/knowledge-center/school-leadership/key-research/Pa ges/Investigating-the-Links-to-Improved-Student-Learning.aspx

Shellard, E. (2003). Defining the principalship. Principal, 82(4), 56-60.

Slenning, K. (2000). The future school manager: Information and communication technology aspects. Educational Media International, 37(4), 243-249. http://dx.doi.org/10.1080/09523980050210439

Smith, W. F., \& Andrews, R.L. (1989). Instructional leadership: How principals make a difference. Alexandria, VA: ASCD.

Strauss, A., \& Corbin, J. (1998). Basics of qualitative research: Techniques and procedures for developing grounded theory ( $2^{\text {nd }}$ ed.). Thousand Oaks, CA: Sage.

Waight, N., \& Abd-El-Khalick, F. (2012). Nature of technology: Implications for design, development, and enactment of technological tools in school science classrooms. 
International Journal of Science Education, 34(18), 2875-2905. http://dx.doi.org/10.1080/09500693.2012.698763

Waight, N., \& Abd-El-Khalick, F. (2007). The impact of technology on the enactment of inquiry in a technology enthusiast's sixth grade science classroom. Journal of Research in Science Teaching, 44, 154-182. http://dx.doi.org/10.1002/tea.20158

Walker, J. (2010). School administration managers (SAMS): Are they making a difference? In C. Manges \& L. Hollingworth (Eds.), Organization and administration of Iowa public and private schools. Dubuque, IA: Kendall Hunt.

\section{Copyright Disclaimer}

Copyright for this article is retained by the author(s), with first publication rights granted to the journal.

This is an open-access article distributed under the terms and conditions of the Creative Commons Attribution license (http://creativecommons.org/licenses/by/3.0/). 